\title{
METFORMIN EXERTS CARDIOPROTECTION IN ISOPROTERENOL-INDUCED CARDIOMYOPATHY IN RATS
}

Introduction. Due to neuropathy in diabetic patients, the dysfunction of the autonomic nervous system occurs, and cardiac activity undergone excess sympathetic stimulation which is named cardiac autonomic neuropathy. Patients with cardiac autonomic neuropathy are at higher risk of left ventricular hypertrophy and are predisposed to cardiovascular events. It was established that metformin, a first-line agent for the initial pharmacotherapy of type 2 diabetes mellitus, poses significant cardioprotective effects. Nevertheless, its activity in the myocardium, subjecting the increased sympathetic tone, remains poorly investigated.

The aim of the study - to explore the effects of metformin on cardiac remodeling after prolonged isoproterenol administration at a low dose.

Research Methods. To induce cardiomyopathy, Wistar rats were injected intraperitoneally with isoproterenol (Iso $-5 \mathrm{mg} / \mathrm{kg}$ ) in the continuous presence of metformin $(M-100 \mathrm{mg} / \mathrm{kg}$ ) or vehicle only for 7 consecutive days. Tissue samples were stained with Hematoxylin\&Eosin using standard method. The serum level of brain natriuretic peptide was estimated using the Rat BNP ELISA Kit. Statistical comparison of multiple groups was performed by one-way ANOVA followed by Bonferroni Test using GraphPad Prism version 5.00.

Results and Discussion. The results of investigation demonstrate that metformin treatment significantly abolished cardiac hypertrophy in rats induced by isoproterenol administration at the daily dose $5 \mathrm{mg} / \mathrm{kg}$ for 7 days. Antihypertrophic effect of the drug was confirmed by its ability to diminish the serum level of brain natriuretic peptide. Structural fibrotic reorganization was prevented as well.

Conclusions. Metformin exerts cardioprotection after prolonged isoproterenol administration at a low dose preventing hypertrophic and fibrotic remodeling and fetal genes reprogramming. Thus, it might be a potential tool in the prevention of cardiac remodeling in patients with sympathetic overactivity.

KEY WORDS: metformin; isoproterenol; hypertrophy; fibrosis; brain natriuretic peptide.

INTRODUCTION. Diabetes mellitus leads to dysfunction in the autonomic nervous system, causing various cardiovascular disorders, i.e. resting tachycardia, postural hypotension, higher intra/ perioperative cardiovascular instability, more frequent asymptomatic myocardial ischemia and infarction, and greater mortality after myocardial infarction [1]. Cardiac autonomic neuropathy (CAN) significantly decreases quality of life and is followed by unfavorable prognosis [2]. CAN is caused by damage of the autonomic nerve fibers that innervate the heart and blood vessels and leads to abnormalities in cardiovascular dynamics [3].

Various pathogenic pathways are involved in the process of CAN development in the diabetic patients, while hyperglycemia is the leading cause of these complex interaction initiation [4]. Hyperglycemia-induced oxidative stress increases mitochon-

(c) H. Ya. Loi, B. V. Pavliuk, S. B. Kramar, M. M. Korda, O. M. Oleshchuk, 2019. drial production of free radicals which together with impaired neuronal activity, membrane permeability, mitochondrial and endothelial function are involved in the pathogenesis of diabetic CAN [5].

Neuropathy first affects the longest nerve fibers. The first feature of diabetic CAN is usually vagus nerve damage. Since this nerve is responsible for nearly $75 \%$ of parasympathetic activity, alteration in its function causes resting tachycardia, since sympathetic influences become predominant [6]. After about five years increased heart rate eventually diminishes due to progressive sympathetic nerve fiber damage, however, it remains higher than in the healthy patients [1]. Declines in parasympathetic tone occur at night and CAN subjects experience more frequent left ventricular hypertrophy and are predisposed to cardiovascular events [7]. Therefore, searching for new therapeutic strategies, which can modulate adverse cardiac remodeling and prevent heart failure, is an urgent matter. 
Metabolic state optimization is considered to be the only effective strategy in the therapy of diabetic CAN [8]. Metformin, according to the American Diabetes Association's current clinical practice recommendations, remains a first line pharmacological agent for type 2 diabetes mellitus treatment [9] that can reduce risk of cardiovascular events and death [10]. The cardioprotective effects of metformin have been considered related to its beneficial actions on lipid metabolism, endothelial function, calcium homeostasis, hypercoagulation, and platelet reactivity [11].

Previously we have reported that metformin protects cardiomyocytes from hypertrophy and apoptosis caused by metabolic stress, hypoxia and ischemia-reperfusion, resulting in gene expression profile changes [12]. Nevertheless, its activity in the myocardium, subjecting the increased sympathetic tone, is still poorly investigated.

The aim of our study was to explore the effects of metformin on cardiac remodeling after prolonged isoproterenol (ISO) administration at a low dose.

RESEARCH METHODS. The study was performed according to the General Ethical Principles for the Use of Animals in Research. The Wistar male rats were maintained in a temperature-controlled room $\left(25^{\circ} \mathrm{C}\right)$ with a natural day/night cycle, fed a standard chow diet and given ad libitum access to water. Animals were randomly divided into 4 groups: $\mathrm{C}$ (vehicle injection), $\mathrm{C}+\mathrm{M}$ (metformin injection), Iso (isoproterenol injection), Iso+M (isoproterenol and metformin injection). To induce cardiomyopathy, rats were injected intraperitoneally with isoproterenol (Iso-5 mg/kg) in the continuous presence of metformin (Met-100 mg/kg) or vehicle only for 7 consecutive days.

Tissue samples were stained with Hematoxylin \& Eosin using standard method. The serum level of brain natriuretic peptide (BNP) was estimated using the Rat BNP ELISA Kit (Elabscience). Statistical comparison of multiple groups was performed by the one-way ANOVA followed by the Bonferroni Test using GraphPad Prism version 5.00 (GraphPad Software, Inc).

RESULTS AND DISCUSSION. First of all the effect of metformin on cardiac hypertrophy was investigated in rats induced by isoproterenol administration for 7 days. Previously it was shown that low doses of isoproterenol $(0.3$ to $6 \mathrm{mg} / \mathrm{kg})$ injected repeatedly during 1-3 weeks induce cardiac hypertrophy accompanied by fibrosis and necrosis of the tissue [13].

As shown in Fig. 1, in the rats with cardiomyopathy, treated with vehicle, isoproterenol caused a two-fold increase in cardiomyocyte size: cell area in the Iso group was $(482.6 \pm 8.78) \mu \mathrm{m}^{2}$ against $(222.3 \pm 3.85) \mu m^{2}$ in the control group, $p<0.001$.

Metformin treatment prevented cardiomyocytes hypertrophic response in the rats with isoproterenol-induced cardiomyopathy: cell area in the Iso+M group was $(285.1 \pm 4.25) \mu \mathrm{m}^{2}$ against $(482.6 \pm 8.78) \mu \mathrm{m}^{2}$ in the Iso group, $p<0.001$.

The data attained from histomorphology analysis, which proved anti-hypertrophic effect of metformin, was further confirmed by the assessment of BNP serum concentration. Previously it was established that cardiac hypertrophy induced by $\beta_{1}$-adrenoreceptors stimulation was followed by increased protein synthesis and upregulation of early response genes, and fetal gene expression (e.g. the natriuretic peptide genes) [14]

It is proved (Fig. 2) that isoproterenol provoked augmentation of serum BNP level in the rats treated with vehicle in $85.5 \%$. Nevertheless, metformin administration significantly declined BNP serum concentration in the rats with isoproterenol-induced cardiomyopathy compare to the untreated animals. This results confirm our previous findings that metformin prevents fetal genes reprogramming [12].

Chronic administration of isoproterenol causes progressive fibrotic changes in the myocardium, which eventually leads to left ventricular dysfunction [15]. Thus, fibrotic remodeling prevention is a prospective therapeutic target in the heart failure treatment [16].

Also, the impact of metformin on fibrotic remodeling in increased sympathetic tonus was studied. Isoproterenol caused the augmentation in fibrotic tissue accumulation in the myocardium of the rats. Metformin treatment prevented fibrotic reprogramming induced by isoproterenol (Fig. 3).

Thus, the conclusion can be drawn that metformin exerts significant cardioprotection in rats with isoproterenol-induced heart damage.

The impact of metformin on hypertrophic and fibrotic reprogramming of myocardium in the rats with isoproterenol-induced cardiomyopathy is presented in the study.

Isoproterenol is a sympathomimetic that acts selectively on beta-adrenergic receptors and produces powerful stimulation of the heart to increase its rate and power of contraction, causing increased cardiac output. It dilates the arterioles of skeletal muscle ( $\beta 2$ effect), resulting in decreased peripheral resistance that greatly reduces mean arterial and diastolic blood pressure [13].

Isoproterenol initiates imbalance between oxygen supplementation to the heart and response from cardiomyocytes, which is related to myocardial hyperfunction due to the increase both in chronotropism and inotropism as well as to hypotension in the coronary bed. Despite of this an elevation of 

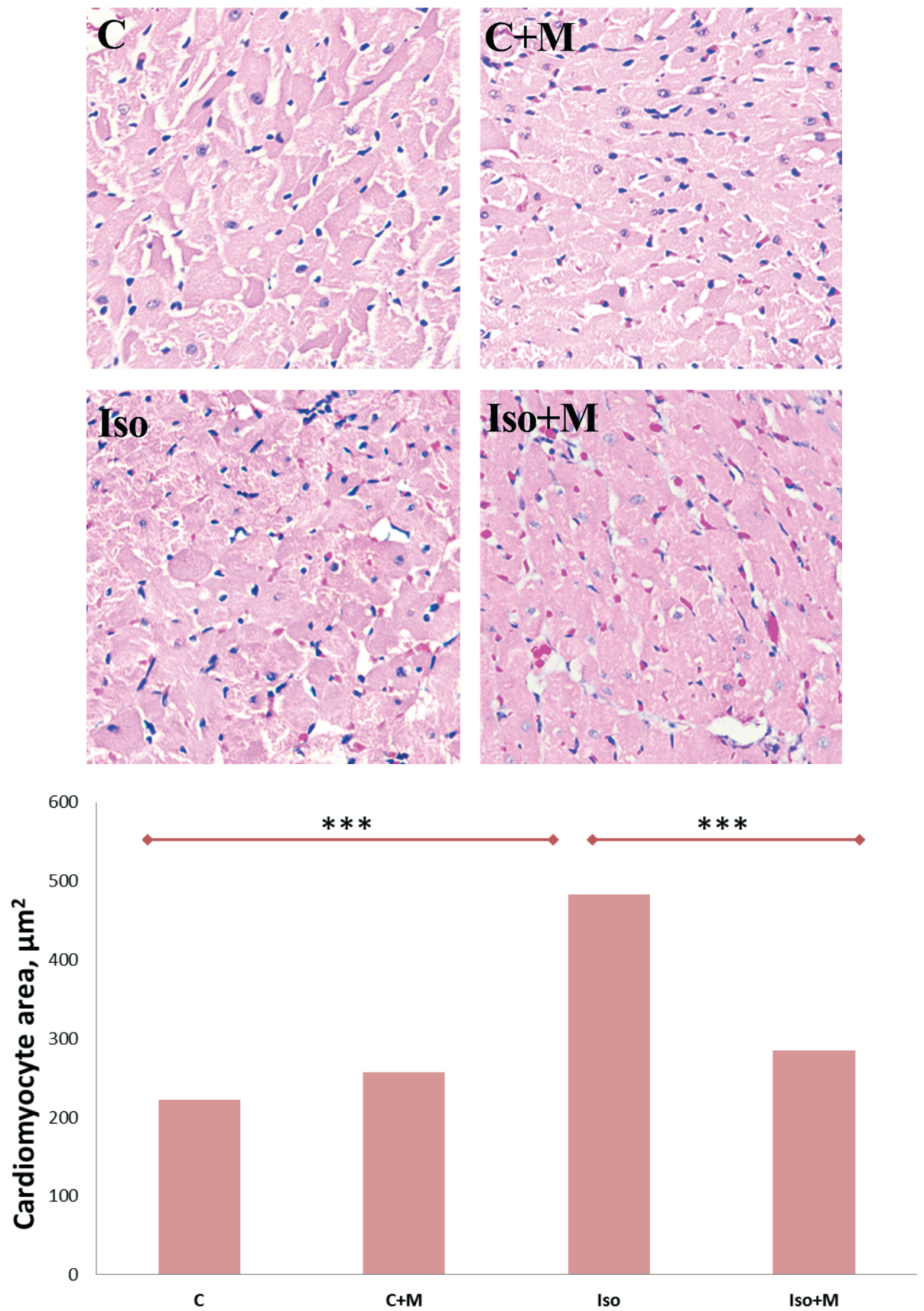

Fig. 1. Metformin decreases cardiomyocyte hypertrophy induced by isoproterenol administration.

Notes. The rats were divided into 4 groups: C (vehicle administration), $\mathrm{C}+\mathrm{M}$ (metformin $(100 \mathrm{mg} / \mathrm{kg})$ administration), Iso (isoproterenol (5 mg/kg) and vehicle administration), Iso+M (isoproterenol $(5 \mathrm{mg} / \mathrm{kg}$ ) and metformin (100 mg/kg) administration). Treatment was maintained for 7 days.

Upper panel - microscopic examination of heart tissue, stained with H\&E. Scale bar is $10 \mu \mathrm{m}$

Lower panel - quantification of cardiomyocyte area.

Data information: Data are presented as mean \pm SEM. Two-way ANOVA followed by Bonferroni's post hoc test: ${ }^{* \star} p<0.001$ between the conditions.

$\mathrm{Ca}^{2+}$ overcharge inside the cell does occur that activates adenylate cyclase enzyme and depletes ATP levels. All these events produce negative impact on the heart, thus isoproterenol is used in the experimental medicine for cardiac injury models inducing [13].

According to the literature analysis the isoproterenol-induced effects on heart could be divided into 3 groups depending on the dose and duration of isoproterenol administration. The high dose of isoproterenol causes myocardial damage as acute myocardial infarction, while at the low doses (0.3$6 \mathrm{mg} / \mathrm{kg}$ ) it produces cardiac injury with the features common for chronic adrenergic hyperactivity [13].

Adrenergic neurotransmitters of the sympathetic nervous system are significant in the regula- 


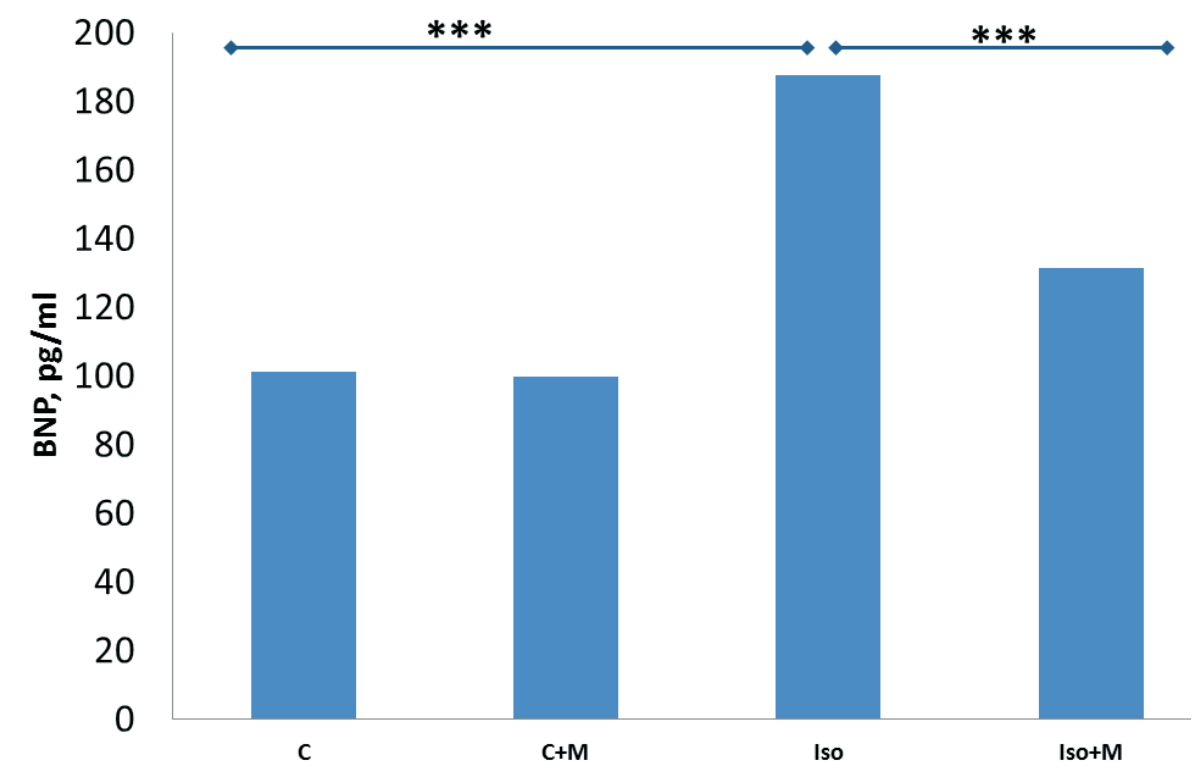

Fig. 2. Metformin declines BNP serum concentration in the rats with isoproterenol-induced cardiomyopathy.

Notes. The rats were divided into 4 groups: C (vehicle administration), C+M (metformin (100 mg/kg) administration), Iso (isoproterenol ( $5 \mathrm{mg} / \mathrm{kg}$ ) and vehicle administration), Iso+M (isoproterenol ( $5 \mathrm{mg} / \mathrm{kg}$ ) and metformin (100 mg/kg) administration). Treatment was conducted for 7 days.

The serum level of BNP was estimated using the Rat BNP ELISA Kit.

Data information: Data are presented as mean \pm SEM. Two-way ANOVA followed by Bonferroni's post hoc test: $* \star \star p<0.001$ between the conditions.

tion of heart activity, although prolonged and extra adrenergic receptors stimulation leads to cardiac dysfunction and cell death [17], and are an important factor in the pathogenesis of cardiomyocyte hypertrophy [18]. Sympathetic overactivity is considered to be an essential feature in the patients with heart failure, and norepinephrine plasma level correlates with the stage of left ventricular dysfunction [19].

In prolonged $\beta$-adrenergic receptors activation, hypertrophic phenotype occurs that is associated with extra protein synthesis, proto-oncogene expression, enchased oxidative stress, inflammation and stimulation of mitogen-activated protein kinase [20].

Besides, $\beta$-adrenergic receptors stimulation is a trigger for fetal genes expression [20], in particular, brain natriuretic peptide (BNP) [14].

BNP expression is increased in heart failure development, and circulating BNP plasma level is a marker of left ventricular dysfunction [14] and is followed by a high risk of mortality in the patients with cardiovascular pathology [21].

The results of histomorphological analysis proved that isoproterenol administration at the low dose for relatively long period induced significant hypertrophic response followed by enlargement of BNP serum level that correlated with the data of the literature reviewed.

Metformin is a clinically widely used oral antidiabetic agent that is extensively used in the treatment of the patients with type 2 diabetes mellitus $[22,23]$. Recent studies have reported that metformin, in addition to its hypoglycemic effect, have anti-inflammatory effects and improved energy metabolism and endothelial function [24, 25], significantly reduces the incidences of great vessel disease and acute myocardial infarction in diabetic patients [26], exertes a cardioprotective effect and attenuated myocardial ischemia/reperfusion injury [27].

In the present study metformin treatment counteracted cardiac hypertrophy by preventing cardiomyocyte growth. Furthermore, brain natriuretic peptide expression was attenuated that was confirmed by ELISA analysis of its serum level.

Due to necrosis of cardiomyocytes induced by isoproterenol, enhanced fibrotic tissue accumulation in the myocardium occurs [28]. Fibrosis, as a main component of cardiac remodeling, includes microscopic scarring, which serves to replace lost contractile cells after necrosis with non-functional scar tissue and thereby is essential in preserving myocardial structure. The extension of fibrosis evidences widespread and ongoing necrosis of cardiomyocytes [29].

Furthermore, an imbalance between synthesis/ degradation of extracellular matrix (ECM) proteins finally results in excessive accumulation of fibrillar collagen, which is found in cardiac fibrosis, stiffen the ventricles and impede both contraction and relaxation, impairing the electrical coupling of cardiomyocytes and the global cardiac function [28].

In the rats administered with isoproterenol for 7 days the development of a pronounced perivas- 

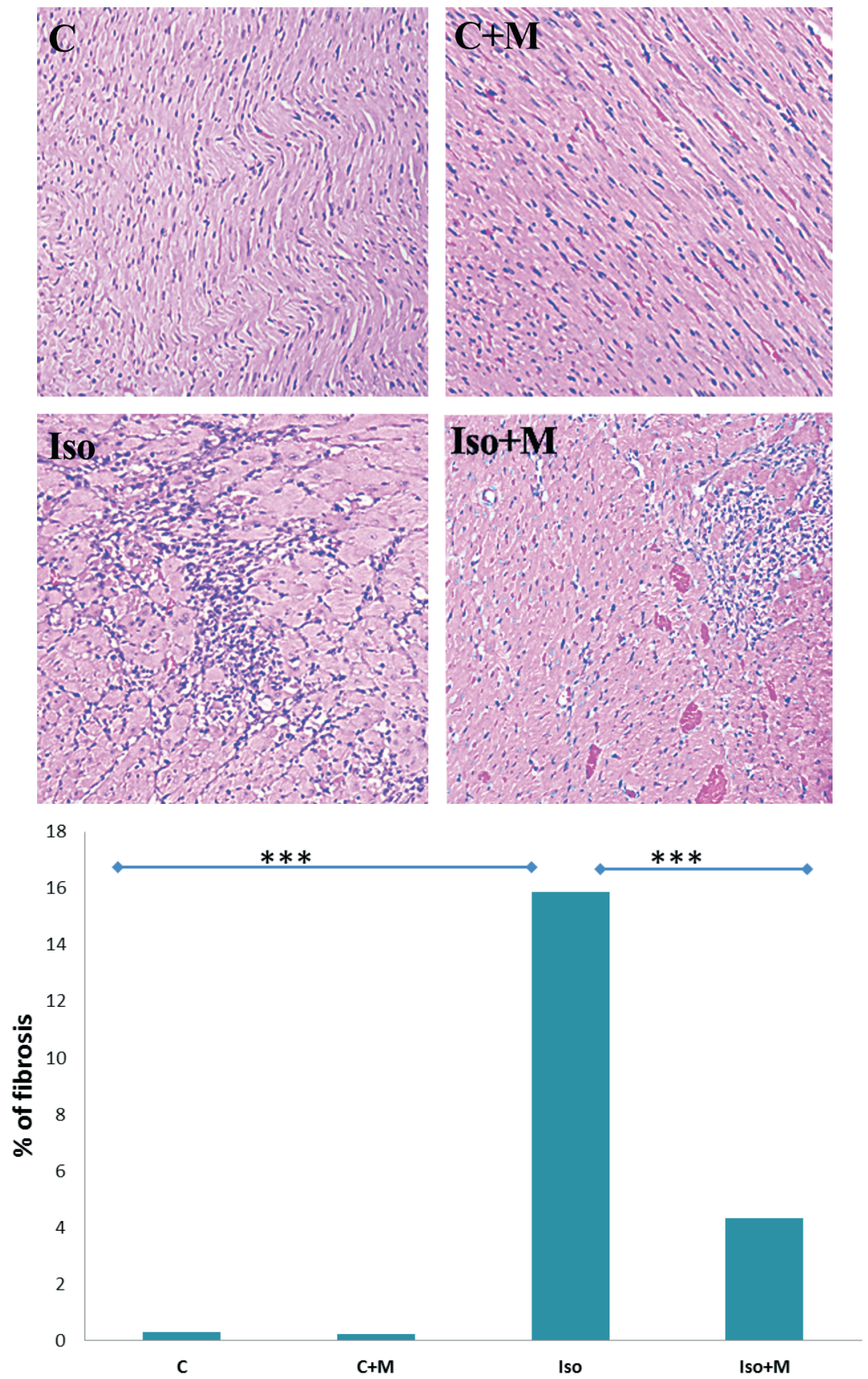

Fig. 3. Metformin decreases extent of fibrosis in the rats with isoproterenol-induced cardiomyopathy

Notes. The rats were divided into 4 groups: C (vehicle administration), C+M (metformin (100 mg/kg) administration), Iso (isoproterenol (5 mg/kg) and vehicle administration), Iso+M (isoproterenol (5 mg/kg) and metformin (100 mg/kg) administration). Treatment was conducted for 7 days.

Upper panel - microscopic examination of the heart tissue, stained with H\&E. Scale bar is $10 \mu \mathrm{m}$.

Lower panel - quantification of cardiomyocyte area.

Data information: Data are presented as mean \pm SEM. Two-way ANOVA followed by Bonferroni's post hoc test: ${ }^{* *} \mathrm{p}<0.001$ between the conditions.

cular and interstitial fibrosis in the myocardium was proved.

Cardiac fibrosis is a major factor in the progression of heart failure thus its prevention might be a potential strategy in the treatment of heart failure [16]. Metformin treatment reduced extent of fibrotic tissue in the hearts of the rats with isoproterenol-induced cardiomyopathy.
CONCLUSIONS. The results prove that metformin exerts significant cardioprotection caused by chronic isoproterenol administration. Thus, it might be a prospective means in prevention of cardiac remodeling in the patients with sympathetic overactivity. Investigation of new mechanisms in the drugs protective action is needed to provide a better understanding of the pharmacodynamic 
particularities. The future perspectives of the study are exploring molecular and genetic targets of the drug, which are involved in the producing of effects aimed to prevent the formation of cardiac remodeling. funding.

Funding. This research received no external

Conflict of Interests. The authors declare no conflict of interest.

\section{LITERATURE}

1. Balcıoğlu A. S. Diabetes and cardiac autonomic neuropathy: Clinical manifestations, cardiovascular consequences, diagnosis and treatment. World Journal of Diabetes / A. S. Balcıoğlu, H. Müderrisoğlu // World Journal of Diabetes. - 2015. - No. 1. - P. 80-91.

2. Neuropatía autonómica en diabetes / I. Aaron, E. M. Raelene, D. Braxton [et al.] // Diabetes Care. 2003. - No. 26. - P. 1553-1579.

3. Cardiac autonomic neuropathy in diabetes: A predictor of cardiometabolic events / A. I. Vinik, C. Casellini, H. K. Parson [et al.] // Frontiers in Neuroscience. 2018. - No. 12. - P. 1-11.

4. Pop-Busui R. Cardiac autonomic neuropathy in diabetes: A clinical perspective / Pop-Busui // Diabetes Care. - 2010. - No. 2. - P. 434-441.

5. Albers J. W. Diabetic neuropathy: mechanisms, emerging treatments, and subtypes / J. W. Albers, R. PopBusui // Current Neurology and Neuroscience Reports. 2014. - No. 14. - P. 473-491.

6. Cardiac autonomic diabetic neuropathy / M. Schönauer, A. Thomas, S. Morbach [et al.] // Diabetes and Vascular Disease Research. - 2008. - No. 5. - P. 336344.

7. Aaron I. V. Diabetic autonomic neuropathy I I. V. Aaron, T. Erbas // In Handbook of Clinical Neurology. 2013. - No. 117. - P. 279-294.

8. Association of hyperglycemia with reduced heart rate variability (The Framingham Heart Study) / J. Singh, M. Larson, C. O'Donnell [et al.] // The American Journal of Cardiology. - 2000. - No. 86. - P. 309-312.

9. American Diabetes Association. Diabetes 2019 Guidelines / American Diabetes Association // Diabetes Care. - 2018. - No. 42. - P. 90-102.

10. Matthews D. R. 10-Year Follow-up of intensive glucose control in type 2 diabetes / D. R. Matthews, H. A. Neil // New England Journal of Medicine. - 2008. No. 359. - P. 1577-1589.

11. Kirpichnikov D. Metformin: An update / D. Kirpichnikov, S. Mcfarlane, J. Sowers // Annals of Internal Medicine. - 2002. - P. 25-33.

12. Metformin protects the heart against hypertrophic and apoptotic remodeling after myocardial infarction / H. Loi, F. Boal, H. Tronchere [et al.] // Frontiers in Pharmacology. - 2019. - No. 10. - P. 154-163.

13. Siddiqui M. Isoprenaline: A tool for inducing myocardial infarction in experimental animals / M. Siddiqui, U. Ahmad, A. Khan // International Journal of Pharmaceutic. - 2016. - No. 6. - P. 1318-1326.

14. Quan $\mathrm{H}$. Isoproterenol and CAMP regulation of the human brain natriuretic peptide gene involves Src and Rac / H. Quan, W. Guiyun, M. LaPointe // American Journal of Physiology. - Endocrinology and Metabolism. 2000. - No. 278. - P. 1115-1123.
15. Brooks W. Isoproterenol-induced myocardial injury and diastolic dysfunction in mice: Structural and functional correlates/W. Brooks, C. Conrad// Comparative Medicine. - 2009. - No. 59. - P. 339-343.

16. Mesenchymal stem cell transplantation attenuates cardiac fibrosis associated with isoproterenol-induced global heart failure / L. Li, Y. Zhang, Y. Li [et al.] // Transplant International. - 2008. - No. 12. - P. 11811189.

17. Isoproterenol instigates cardiomyocyte apoptosis and heart failure via AMPK inactivation-mediated endoplasmic reticulum stress / X. Zhuo, Y. Wu, Y. Ni [et al.] // Apoptosis. - 2013. - No. 7. - P. 800-810.

18. A proteomic view of isoproterenol induced cardiac hypertrophy: Prohibitin identified as a potential biomarker in rats / D. Chowdhury, A. Tangutur, T. Khatua [et al.] // Journal of Translational Medicine. - 2013. - No. 1. P. 130-143.

19. Isoproterenol and angiotensin I-converting enzyme in lung, left ventricle, and plasma during myocardial hypertrophy and fibrosis / M. Ocaranza, M. DíazAraya, G. Chiong [et al.] // Journal of Cardiovascular Pharmacology. - 2002. - No. 2. - P. 246-254.

20. Dimethyl fumarate interferes with MyD88dependent toll-like receptor signalling pathway in isoproterenol-induced cardiac hypertrophy model / A. Ahmed, A. Ahmed, E. Morsy [et al.] // Journal of Pharmacy and Pharmacology. - 2018. - No. 11. - P. 1521-1530.

21. Vanderheyden M. Brain and other natriuretic peptides: Molecular aspects / M. Vanderheyden, J. Bartunek, M. Goethals // European Journal of Heart Failure. - 2004. - No. 3. - P. 261-268.

22. Group The Diabetes Prevention Program Research. Long-term safety, tolerability, and weight loss associated with metformin in the diabetes prevention program outcomes study / Group The Diabetes Prevention Program Research // Diabetes Care. - 2012. No. 4. - P. 731-737.

23. The Diabetes Prevention Program Research Group. The 10-year cost-effectiveness of lifestyle intervention or metformin for diabetes prevention: An intentto-treat analysis of the DPP/DPPOS / The Diabetes Prevention Program Research Group // Diabetes Care. 2012. - No. 4. - P. 723-730.

24. Isoda K. Metformin inhibits proinflammatory responses and nuclear factor- $\mathrm{KB}$ in human vascular wall cells / K. Isoda, A. Zirlik, J. Young. // Arteriosclerosis, Thrombosis, and Vascular Biology. - 2006. - No. 3. P. 611-617.

25. Metformin restores endothelial function in aorta of diabetic rats / C. Sena, P. Matafome, T. Louro [et al.] // British Journal of Pharmacology. - 2011. - No. 2. P. 424-437. 
26. Saloua E. Metformin therapy in diabetes: the role of cardioprotection / E. Saloua, A. Gerard, N. Rongen // Current Atherosclerosis Reports. - 2013. - No. 4. P. 314-330.

27. Metformin induces cardioprotection against ischaemia/reperfusion injury in the rat heart 24 hours after administration / L. Solskov, L. Løfgren, S. Kristiansen [et al.] //Basic and Clinical Pharmacology and Toxicology. 2008. - No. 1. - P. 82-87.

\section{REFERENCES}

1. Balcıoğlu, A.S., \& Müderrisoğlu, H. (2015). Diabetes and cardiac autonomic neuropathy: Clinical manifestations, cardiovascular consequences, diagnosis and treatment. World J. Diabetes, 6 (1), 80-91. doi: 10.4239/ wjd.v6.i1.80.

2. Aaron, I., Vinik, Raelene, E. Maser, Braxton, D. Mitchell, \& Roy Freeman (2003). Neuropatía autonómica en diabetes. Diabetes Care, 26 (5), 1553-1579. doi: 10.2337/diacare.26.5.1553.

3. Vinik, A.I., Casellini, C., Parson, H.K., Colberg, S.R., \& Nevoret, M.L. (2018). Cardiac autonomic neuropathy in diabetes: A predictor of cardiometabolic events. Front Neurosci., 12, 1-11. doi: 10.3389/fnins. 2018.00591.

4. Pop-Busui, R. (2010) Cardiac autonomic neuropathy in diabetes: A clinical perspective. Diabetes Care, 33 (2), 434-41. doi: 10.2337/dc09-1294.

5. James, W. Albers. (2014). Diabetic neuropathy: Mechanisms, emerging treatments, and subtypes. Curr. Neurol. Neurosci. Rep., 14 (8), 473-491. doi: $10.1007 /$ s11910-014-0473-5.

6. Schönauer, M., Thomas, A., Morbach, S., Niebauer, J., Schönauer, U., \& Thiele, H. (2008). Cardiac autonomic diabetic neuropathy. Diabetes Vasc. Dis. Res. 5 (4), 336-344. doi: 10.3132/dvdr.2008.047

7. Aaron, I. Vinik, \& Erbas, T. (2013). Diabetic autonomic neuropathy. In Handbook of Clinical Neurology, 117, 279-294.

8. Singh, J.P., Larson, M.G., O'Donnell, C.J., Wilson, P.F., Tsuji, H., Lloyd-Jones, D.M., \& Levy, D. (2000). Association of hyperglycemia with reduced heart rate variability (The Framingham Heart Study). Am. J. Cardiol., 86 (3), 309-312. doi: 10.1016/S0002-9149(00)00920-6.

9. (2018). American Diabetes Association. Diabetes 2019 Guidelines. Diabetes Care, 42 (1), 90-102. doi: 10.2337/dc19-S009.

10. Matthews, D.R., \& Neil, H.A.W. (2008). 10-year follow-up of intensive glucose control in type 2 diabetes. N. Engl. J. Med., 359, 1577-1589. doi: 10.1056/NEJMoa0806470.

11. Kirpichnikov, D., Mcfarlane, S.I., \& Sowers, J.R (2002). Metformin: An update. Ann. Intern. Med., 137, 25-33. doi: 10.7326/0003-4819-137-1-200207020-00009.

12. Loi, H., Boal, F., Tronchere, H., Cinato, M., Kramar, S., Oleshchuk, O. et al. (2019). Metformin protects the heart against hypertrophic and apoptotic remodeling after myocardial infarction. Front. Pharmacol., 10, 154. doi: 10.3389/fphar.2019.00154.
28. Attenuation of endoplasmic reticulum stress using the chemical chaperone 4-phenylbutyric acid prevents cardiac fibrosis induced by isoproterenol / P. Ayala, J. Montenegro, R. Vivar [et al.] // Experimental and Molecular Pathology. - 2012. - No. 1. - P. 97-104.

29. Cellular and molecular pathways to myocardial necrosis and replacement fibrosis / M. Gandhi, G. Kamalov, A. Shahbaz [et al]. // Heart Failure Reviews. 2011. - No. 1. - P. 23-34.

13. Siddiqui, M.A., Ahmad, U., Khan, A.A., Ahmad, M., Badruddeen, Khalid, M., et al. (2016). Isoprenaline: A tool for inducing myocardial infarction in experimental animals. Int. J. Pharm., 6 (1), 1318-1326.

14. Quan, H., Guiyun, W., \& LaPointe, M.C. Isoproterenol and CAMP regulation of the human brain natriuretic peptide gene involves Src and Rac. Am. J. Physiol. - Endocrinol. Metab., 278, 1115-23. doi: 10.1152/ ajpendo.2000.278.6.E1115.

15. Brooks, W.W., \& Conrad, C.H. (2009). Isoproterenol-induced myocardial injury and diastolic dysfunction in mice: Structural and functional correlates. Comp. Med., 59 (4), 339-343.

16. Li, L., Zhang, Y., Li, Y., Yu, B., Xu, Y., Zhao, S.D., et al. (2008). Mesenchymal stem cell transplantation attenuates cardiac fibrosis associated with isoproterenolinduced global heart failure. Transpl. Int., 21 (12), 11811189. doi: 10.1111/j.1432-2277.2008.00742.x.

17. Zhuo, X.Z., Wu, Y., Ni, Y.J., Liu, J.H., Gong, M., Wang, X.H., et al. (2013). Isoproterenol instigates cardiomyocyte apoptosis and heart failure via AMPK inactivation-mediated endoplasmic reticulum stress. Apoptosis, 18 (7), 800-810. doi: 10.1007/s10495-013-0843-5.

18. Chowdhury, D., Tangutur, A.D., Khatua, T.N., Saxena, P., Banerjee, S.K., Bhadra, M.P. (2013). A proteomic view of isoproterenol induced cardiac hypertrophy: Prohibitin identified as a potential biomarker in rats. J. Transl. Med., 11 (1), 130-143. doi: 10.1186/1479-587611-130.

19. Ocaranza, M.P., Díaz-Araya, G., Chiong, M., Muñoz, D., Riveros, J.P., Ebensperger, R., et al. (2002). Isoproterenol and angiotensin l-converting enzyme in lung, left ventricle, and plasma during myocardial hypertrophy and fibrosis. J. Cardiovasc. Pharmacol., 40 (2), 246-254. doi: 10.1097/00005344-200208000-00010.

20. Ahmed, A.A., Ahmed, A.A.E., El Morsy, E.M., \& Nofal, S. (2018). Dimethyl fumarate interferes with MyD88-dependent toll-like receptor signalling pathway in isoproterenol-induced cardiac hypertrophy model. $\mathrm{J}$. Pharm. Pharmacol., 70 (11), 1521-1530. doi: 10.1111/ jphp.13000.

21. Vanderheyden, M., Bartunek, J., \& Goethals, M. (2004). Brain and other natriuretic peptides: Molecular aspects. Eur. J. Heart Fail., 6 (3), 261-268. doi: 10.1016/j. ejheart.2004.01.004.

22. (2012). Group The Diabetes Prevention Program Research. Long-term safety, tolerability, and weight loss associated with metformin in the diabetes prevention 
program outcomes study. Diabetes Care, 35 (4), 731-737. doi: 10.2337/dc11-1299.

23. (2012). The Diabetes Prevention Program Research Group. The 10-year cost-effectiveness of lifestyle intervention or metformin for diabetes prevention: An intent-to-treat analysis of the DPP/DPPOS. Diabetes Care, 35 (4), 723-730. doi: 10.2337/dc11-1468.

24. Isoda, K., Young, J.L., Zirlik, A., MacFarlane, L.A., Tsuboi, N., Gerdes, N., et al. (2006). Metformin inhibits proinflammatory responses and nuclear factor-kB in human vascular wall cells. Arterioscler Thromb. Vasc. Biol., 26(3),611-617. doi:10.1161/01.ATV.0000201938.78044.75.

25. Sena, C.M., Matafome, P., Louro, T., Nunes, E., Fernandes, R., \& Seiça, R.M. (2011). Metformin restores endothelial function in aorta of diabetic rats. Br. J. Pharmacol., 163 (2), 424-437. doi: 10.1111/j.1476-5381. 2011.01230.x

26. Saloua, E., Messaoudi Gerard, A., Rongen Niels P. Riksen (2013). Metformin therapy in diabetes: the role of cardioprotection. Curr. Atheroscler. Rep., 15 (4), 314330. doi: 10.1007/s11883-013-0314-z.

27. Solskov, L., Løfgren, B., Kristiansen, S.B., Jessen, N., Pold, R., \& Nielsen, T.T., et al. (2008). Metformin induces cardioprotection against ischaemia/reperfusion injury in the rat heart 24 hours after administration. Basic Clin. Pharmacol. Toxicol., 103 (1), 82-87. doi: 10.1111/j.1742-7843.2008.00234.x.

28. Ayala, P., Montenegro, J., Vivar, R., Letelier, A., Urroz, P.A., Copaja, M., et al. (2012). Attenuation of endoplasmic reticulum stress using the chemical chaperone 4-phenylbutyric acid prevents cardiac fibrosis induced by isoproterenol. Exp. Mol. Pathol., 92 (1), 97-104. doi: 10.1016/j.yexmp.2011.10.012.

29. Gandhi, M.S., Kamalov, G., Shahbaz, A.U., Bhattacharya, S.K., Ahokas, R.A., Sun, Y., et al. (2011). Cellular and molecular pathways to myocardial necrosis and replacement fibrosis. Heart Fail Rev., 16 (1), 23-34. doi: 10.1007/s10741-010-9169-3.

\section{МЕТФОРМІН ПРОЯВЛЯЄ КАРДІОПРОТЕКЦІЮ ПРИ ІЗОПРОТЕРЕНОЛІНДУКОВАНІЙ КАРДІОМІОПАТІЇ В ЩУРІВ}

\section{Резюме}

Вступ. У хворих на цукровий діабет у зв'язку з нейропатією виникає дисфункиія автономної нервової системи, внаслідок чого серцева діяльність піддається надмірній симпатичній стимуляції, що називають кардіальною автономною нейропатією. Пацієнти з нейропатією мають підвищений ризик виникнення гіпертрофії лівого шлуночка та більш схильні до розвитку серцево-судинних ускладнень. Встановлено, що меторормін, препарат першої лінії для початкової фрармакотерапії цукрового діабету 2 типу, проявляє виражені кардіопротекторні ефекти. Проте його активність у міокарді, що піддається надмірному симпатичному впливу, вивчено недостатньо.

Мета дослідження - встановити ефректи метформіну на кардіальне ремоделювання, викликане пролонгованим введенням ізопротеренолу в низькій дозі.

методи дослідження. Щоб викликати кардіоміопатію, щурам лінії Вістар внутрішньочеревно вводили ізопротеренол (Iso - 5 мг/кг) за присутності метфрорміну (M - 100 мг/кг) або фрізрозчину впродовж 7-ми днів. Зразки тканин було зафарбовано гематоксиліном і еозином з використанням стандартного методу. Сироватковий рівень мозкового натрійуретичного пептиду досліджено за допомогою Rat BNP ELISA Kit. Однофракторний дисперсійний аналіз ANOVA з попарним порівнянням груп за критерієм Бонфрероні проведено для статистичної оцінки результатів за допомогою програми GraphPad Prism версії 5.00.

Результати й обговорення. У результаті проведених досліджень встановлено, що лікування метформіном достовірно зменшує серцеву гіпертрофрію в щурів, індуковану введенням ізопротеренолу в дозі 5 мг/кг протягом 7-ми днів. Антигіпертрофрічний ефект препарату підтверджено тим, що його застосування сприяло зниженню рівня мозкового натрійуретичного пептиду в сироватці крові. Структурні орібротичні зміни в міокарді було також попереджено.

Висновки. Меторормін проявляє кардіопротекцію при пролонгованому введенні ізопротеренолу в низькій дозі, запобігаючи гіпертрофрічному та фрібротичному ремоделюванню і репрограмуванню фретальних генів. Тому препарат може бути потенційним засобом для профрілактики ремоделювання міокарда, спричиненого надмірною активністю симпатичної нервової системи в пацієнтів.

КЛЮЧОВІ СЛОВА: метформін; ізопротеренол; гіпертрофрія; фріброз; мозковий натрійуретичний пептид. 


\section{МЕТФОРМИН ПРОЯВЛЯЕТ КАРДИОПРОТЕКЦИЮ ПРИ ИЗОПРОТЕРЕНОЛИНДУЦИРОВАННОЙ КАРДИОМИОПАТИИ У КРЫС}

\section{Резюме}

Вступление. У больных сахарным диабетом в связи с нейропатией возникает дисфункция автономной нервной системы, в результате чего сердечная деятельность подвергается чрезмерной симпатической стимуляции, что называют кардиальной автономной нейропатией. Пациенты с нейропатией имеют повышенный риск возникновения гипертрофрии левого желудочка и более склонны к развитию сердечно-сосудистых осложнений. Установлено, что меторормин, препарат первой линии для начальной фрармакотерапии сахарного диабета 2 типа, проявляет выраженные кардиопротекторные эфрфекты. Однако его активность в миокарде, что подвергается чрезмерному симпатическому воздействию, изучено недостаточно.

Цель исследования - установить эффректы метформина на кардиальное ремоделирование, вызванное пролонгированным введением изопротеренола в низкой дозе.

Методы исследования. Чтобы вызвать кардиомиопатию, крысам линии Вистар внутрибрюшно вводили изопротеренол (Iso - 5 мг/кг) в присутствии метформина (M - 100 мг/к2) или фризраствора в течение 7-ми дней. Образцы тканей были окрашены гематоксилином и эозином с использованием стандартного метода. Сывороточный уровень мозгового натрийуретического пептида исследован с помощью Rat BNP ELISA Kit. Однофракторный дисперсионный анализ ANOVA с попарным сравнением групп по критерию Бонфрерони проведен для статистической оценки результатов с помощью программы GraphPad Prism версии 5.00.

Результаты и обсуждение. В результате проведенных исследований установлено, что лечение меторормином достоверно уменьшает сердечную гипертрофию у крыс, индуцированную введением изопротеренола в дозе 5 мг/кг в течение 7-ми дней. Антигипертрофрический эфрфект препарата подтвержден тем, что его применение способствовало снижению уровня мозгового натрийуретического пептида в сыворотке крови. Структурные фрибротические изменения в миокарде были также предупреждены.

Выводы. Метоормин проявляет кардиопротекцию при пролонгированном введении изопротеренола в низкой дозе, предотвращая гипертрофическое и фрибротическое ремоделирование и репрограммирование фретальных генов. Поэтому препарат может быть потенциальным средством для профилактики ремоделирования миокарда, вызванного чрезмерной активностью симпатической нервной системы у пациентов.

КЛЮЧЕВЫЕ СЛОВА: метформин; изопротеренол; гипертрофия; фиброз; мозговой натрийуретический пептид.

Received 09.10.19

Address for correspondence: H. Ya. Loi, I. Horbachevsky Ternopil National Medical University, Maydan Voli, 1, Ternopil, 46001, Ukraine, e-mail: loy@tdmu.edu.ua. 